\title{
10
}

\section{Jane Eyre's Legacy: The Powers and Dangers of Singularity}

It is the fact of your telling, whether they believe you or not... It will help other women to speak out what they think, unashamed.

-Mary Austin, A Woman of Genius

Discourse conceals its incompleteness.

- Lawrence Hogue, Discourse and the Other

Sometimes there appears a work of literature so seemingly singular that it obscures Virginia Woolf's reminder that "masterpieces" are not "solitary births." Jane Eyre is such a book; when it appeared in 1847 under the sexually ambiguous pseudonym Currer Bell, whether its originality pleased or scandalized, "for everyone Jane Eyre was 'new.' "2 No aspect of this novel is more sharply singular in every sense than its narrative voice, which has been perceived as almost tyrannical in its power to impose a stance. In the grudging words of Frederic Harrison, "the plain little governess dominates the whole book and fills every page. Everything and every one appear, not as we see them and know them in the world, but as they look to a keen-eyed girl who had hardly ever left her native village." Yet Harrison believes the novel "would have been a failure" if "cast into the form of impersonal narration," while "as the autobiography of Jane Eyre" it is "consum-

1. Virginia Woolf, A Room of One's Oum (New York: Harcourt Brace, 1929), 68-69.

2. Miriam Allott, ed., "Jane Eyre" and "Villette": A Casebook (London: Macmillan, 1973), 20. 
mate art." ${ }^{3}$ One of the earliest fictional autobiographies directed to a public narratee, Jane Eyre has no precedent in the authority it claims for a female personal voice. Yet Jane Eyre's voice is not quite a "single and solitary birth"; it is a transformation of possibilities already present in fiction but segregated along gender lines. I will suggest that the form of Jane Eyre involves the imposition of the self-authorizing and totalizing voice I have associated with the Romantic hero upon a very different and particularly female genre.

Fictional autobiography was still young in 1847 , and not surprisingly nineteenth-century women published fewer fiction or "nonfictional" autobiographies than men. While Jerome Beaty may be right to claim that by 1847 "a novel in the autobiographical mode appearing in England" might be "an apologia or an exemplum, egoistic and Byronic, or humbly Providential," "egoistic and Byronic" fictions in the female voice seem not to have existed, as Beaty's own examples suggest. Instead, female personal voice took form at least in early nineteenth-century England by synthesizing two fictions of dependency-the courtship novel and the spiritual autobiography-into the "governess tale," the story of a dependent woman's progress to spiritual and material happiness. At least three such novels precede Jane Eyre in creating a public voice: Mary Brunton's Discipline (1815); Mary Martha Sherwood's Caroline Mordaunt (1835); and Anne Brontë's Agnes Grey, published in 1847 but written before Charlotte Brontë wrote Jane Eyre. ${ }^{5}$ While each of these novels adopts a voice grammatically female, however, each also limits the narrator's personal authority by appealing to (masculine) authorities outside the self. The governess tales that make Jane Eyre possible, therefore, also make it unique, for Jane will challenge these limits on female authority in her attempt to create an "egoistic" if not "Byronic" narrative subject engaging with uncommon insistence a public narratee. At the same time,

3. Frederic Harrison, cited in Kenneth Graham, English Criticism of the Novel 1865-19oo (Oxford: Clarendon Press, 1964), 129. Note Harrison's typical conflation of author and character: "as the autobiography of Jane Eyre-let us say at once of Charlotte Brontë..."

4. Jerome Beaty, "Jane Eyre at Gateshead: Mixed Signals in the Text and Context," in Victorian Literature and Society: Essays Presented to Richard D. Altick, ed. James R. Kincaid and Albert J. Kuhn (Columbus: Ohio State University Press, 1983), 186.

5. The relationship between Jane Eyre and other governess novels is discussed, though not in terms of voice, by both Jerome Beaty in "Jane Eyre at Gateshead" and Inga-Stina Ewbank in Their Proper Sphere (Cambridge: Harvard University Press, 1966). On the material situation of the governess and its representation in Jane Eyre, see Mary Poovey, Uneven Developments: The Ideological Work of Gender in Mid-Victorian England (Chicago: University of Chicago Press, 1988), chap. 5 . 
as I will argue at the end of this chapter, Jane's voice has a dangerously unacknowledged dependence of its own.

The governess narrative that I believe Jane Eyre is rewriting traces the fortunes of an intelligent gentlewoman in reduced circumstances. Although Ellen Percy, the clever, beautiful, and spoiled heroine of Discipline, begins life in the bosom of luxury, she eventually finds herself orphaned, penniless, and ill; her deprivations foster a conversion to virtue that is ultimately rewarded by marriage to the excellent man she once proudly spurned. Sherwood's spoiled, outspoken, and arrogant Caroline Mordaunt chafes at her subordination as governess and ends up leaving or being dismissed from post after post until she is inspired to holiness by her pupil Emily Selburn, probably a prototype for Helen Burns, who dies at fourteen after "a rapid ripening for a higher state of being." Although no love plot runs through this book, Caroline is rewarded on the final page when the "humble rector of the parish" seeks her hand. Agnes Grey, virtuous from the start, is sorely tested by humiliations and deprivations that, all three novels stress, are the particular lot of the governess, but in the end it is the plain Agnes, not her beautiful and wealthy charge, who gets the handsome clergyman.

It is not surprising, since public personal voice is still so unconventional in fiction by women, that each of these narrators takes some trouble both to bolster her authority and to mitigate the selfcenteredness of her narrative act. Discipline, which may well be the first novel written by a woman anywhere in Europe that uses a public female personal voice exclusively, places itself in the tradition of spiritual autobiography by titling itself after an abstract, virile ideal and by beginning the character's story with so much focus on patrilineage that only midway into the first chapter does a coy reference reveal that the protagonist is of "feminine character."" The narrators of all three novels construct their narratees as judges to be pleased, appeased, or instructed, and they address these "readers" only in distanced, often anxious, third-person forms. Caroline Mordaunt will ask regularly whether her reader is "weary" (232), or "tired of me"

6. Mary Martha Sherwood, Caroline Mordaunt, or, The Governess, in The Works of Mrs. Sherwood (New York: Harper and Brothers, 1835), vol. 13, 281. Further references will appear in the body of the text.

7. Mary Brunton, Discipline (London: Routledge and Kegan Paul, 1986), 4. Further references will appear in the body of the text. 
(252) and will report eagerly something she thinks "my pious reader will be pleased to hear" (263). Ellen Percy, though much less servile, uses anticipated judgments as occasions to sermonize: "Before my reader comment on the wisdom of this reply, let him examine, whether there be any more weight in the reasons which delay his own endeavours after Christian perfection" (28), or, "Others may smile at this and many other instances of my folly. I look back upon them as on the illusions of delirium, and shudder whilst I smile" (83). In Agnes Grey, which seems to take self-judgment so seriously that one may suspect some irony to be at work, the reader is evoked to forgive behaviors that are hardly culpable, as with Agnes's "confession" that she paid "more attention to dress than I had ever done before," or her fear that "the reader is well-nigh disgusted with the folly and weakness" of feeling worthy of Mr. Weston's love. ${ }^{8}$

As such addresses suggest, it is not only the reader but the older "I" who is constructed as authoritative judge. All three novels are explicitly retrospective, narrated by women who have been "many years a wife" (Discipline, 375), and all three profess "instruction" as their goal. In the first two novels, narrative authority demands this temporal gap: the narrator looks back with sharp moral distance at the younger character and can tell her story only because she has changed. This confessional strategy is most obvious in Caroline Mordaunt, the most evangelical of the three novels, whose narrator says she does not "have any good to say of myself," but "much, very much to say of the various providences by which I was gradually brought to know myself, to esteem myself as the chiefest of sinners, and to comprehend in some degree what the Almighty has done and is still doing for me" (252). Ellen Percy, having "escaped from eminent peril," hopes "to warn others of the danger of their way" (1-2). These texts must distinguish sharply between the protagonist and the mature, detached narrator who can look back critically upon her former self. Indeed, the narrator is authorized to the extent that she has accepted a truth that is both Christian and male: in all three novels there are wise God-fearing men (Ellen's uncle and later her benefactor-husband, Agnes's clergyman spouse) who "know better" than the heroine. In this respect the novels recall Hannah More's very popular

8. Anne Brontë, Agnes Grey (London: J. M. Dent, 1985), chap. 17, 114,121 . Further references are to this edition and will appear in the body of the text. 
Coelebs in Search of a Wife (1808), in which a male narrator so selfauthorizing that he is his own introducer and editor is presented, as I said in Chapter 4, as the ultimate expert on Christian womanhood.

The governess tales that precede Jane Eyre stop short of full selfauthorization, then, by making the narrator's authority contingent on submission to an implicit over-voice, the joint construction of the older self and the Christian God who has transformed the protagonist to a worthy autobiographer. In this way, the right to narrate becomes virtue's mandate and reward. In two of the novels the character's (speaking) voice must explicitly be tamed so that the narrator's (writing) voice may serve higher purposes: Ellen Percy's outspokenness lands her in a hospital for the insane and Caroline Mordaunt's costs her several positions. All three novels make clear that silence is the condition of governess, which is in turn but an extreme of the dependent condition of womanhood: "it was my business to hear, and not to speak" (Agnes Grey, 18.127). Agnes survives because "I was used to wearing a placid smiling countenance when my heart was bitter within me" (17.120), and she is rewarded because she passively lets "time and patience" improve her situation "slowly, it is true, and almost imperceptibly" (7.59). Despite their suffering, beyond a passing recognition of the limited "market for the fruits of feminine ingenuity" (Discipline, 244) none of these narrators explicitly questions traditional gender roles. The counterpart, for example, to Jane Eyre's passionate defense (in chapter 12) of women's need for liberty that begins with "Anybody may blame me who likes" is Agnes's long "confession" defending her preoccupation with physical appearance after she has fallen in love (17.114-15).

At the same time, these novels do bear signs of restlessness with their own submissive and pious femininity. Caroline Mordaunt apologizes for recounting a time when "religion had no influence whatever upon my conduct" (212) but takes four-fifths of its pages to present the outspoken, brash, and self-centered behavior of the younger "infidel." Brunton's narrator parades her moral superiority: "there are few who, like me, unfold their temptations, or record their repentance" (243). And each text arguably writes "beyond the ending" by inscribing some ambivalence toward the marriage that ends the tale. Caroline Mordaunt barely mentions her husband, focuses on her children and her "King"; her final word is a reminder that "God is love" (303). Ellen Percy speaks with praise of her unmarried sister-in-law, 
whom "some misses lately arrived from a boarding school have begun to call... an old maid" and insists that the single state has not "produced any ill effect on Charlotte's temper, or on her happiness." She also refuses to compare her own present happiness to her past pleasures, claiming that "the Lowland tongue wants energy for the contrast" (375). And what are we to make of the ending of Agnes Grey, which is surely undercut by this language of negativity surprisingly close to that of the coded letter from the American bride: "I became the wife of Edward Weston; and never have found cause to repent it, and am certain that I never shall.... for whatever his faults may be as a man (and no one is entirely without), I defy anybody to blame him as a pastor, a husband, or a father"? From where would such blame come, when Edward has been presented to us as goodness itself, or are we also to take as literal Agnes's earlier statement that "it is not the man, it is his goodness that I love" (16.11 1 )?

Despite these small signs of resistance, the governess narrators are very distant in spirit from the Romantic voices I described in Chapter 9. In turning the governess tale toward the conventions of Romantic subjectivity, Jane Eyre will expose the authority of these earlier governess narrators as only fictively female and singular-as occupying the ideological positions of men. In Agnes Grey, of course, both the possibilities and the limits of the governess narrative are literally brought home to the author of Jane Eyre: Anne wrote Agnes Grey while Charlotte was completing The Professor, her novel in a male voice that could not find a publisher; Rebecca Rodolff argues persuasively that Agnes Grey probably inspired Charlotte Brontë to begin a new novel in a female voice. ${ }^{9}$ Agnes Grey also attempts, if obliquely, to transform the indirect narrator-narratee relationship of the earlier governess tales to the direct contact represented in Jane Eyre. In its promise "candidly [to] lay before the public" the substance of Agnes's diaries, which "I would not disclose to the most intimate friend" (1.1), Agnes Grey constructs a bridge between the private forms of eighteenthcentury fiction and the public autobiography of Jane Eyre. Yet Anne Brontë's narrator also models a feminine submissiveness that Charlotte's will openly reject.

If Jane Eyre has a dominant agenda, I believe it is to crowd out 
competition in order to authorize as original and self-sufficient the voices of both "Charlotte Brontë" and "Jane Eyre." As Brontë writes in a letter to W. S. Williams in 1848 ,

The standard heroes and heroines of novels are personages in whom I could never from childhood upwards take an interest, believe to be natural, or wish to imitate. Were I obliged to copy these characters I would simply not write at all. Were I obliged to copy any former novelist, even the greatest, even Scott, in anything, I would not write. Unless I have something of my own to say, and a way of my own to say it in, I have no business to publish. Unless I can look beyond the great Masters, and study Nature herself, I have no right to paint. Unless I can have the courage to use the language of Truth in preference to the jargon of Conventionality, I ought to be silent. ${ }^{10}$

Not only does this letter insist upon an ethos of originality that women like Mary Shelley were shy to claim, it also rejects an explicitly male literary tradition in preference for a (female) "Nature" that gives Brontë not just "something of my own to say," but "a way of my own to say it in." A close look at the narrative practices that create Jane Eyre's singular voice suggests that virtually trait for trait Brontë is rejecting the fictions of authority that fashion the governess tales.

While the governess novels rely on temporal and spiritual differences between narrator and protagonist, Jane Eyre relies on their identity. The absence of any attention to the act of narration in the chapters preceding Jane's arrival at Thornfield reinforces a more general masking of the distinction in Jane Eyre between the experiencing child and the narrating adult. Although the young Jane does learn from her mistakes, the narrator never seriously criticizes her, and the narrator's values are more- or-less continuous with those of the younger character. In the famous passage in chapter 12 about a woman's need for liberty, for example, Jane's discourse mingles past and present tense, as if evoking the experiencing and the narrating selves at once: "Who blames me? Many, no doubt; and I shall be called discontented. I could not help it: the restlessness was in my nature; it agitated me to pain sometimes... It is in vain to say human beings ought to be satisfied with tranquillity: they must have action... women feel just as men feel" (95-96). Brontë's generalizing "I" emphasizes syntactically

10. Charlotte Brontë, letter to W. S. Williams of September 1848 , cited in Jane Eyre, ed. Richard Dunn (New York: Norton, 1971), 424. References to Jane Eyre are from this edition and will appear in the text with chapter numbers given first. 
the harmony between the younger protagonist and the older voice: what the one did the other still supports. The young Jane, in sharp contrast to the earlier characters, is already her own moral authority even when her understanding is admitted to be limited. While containment or diminution of voice was necessary for the progress of Ellen Percy, Caroline Mordaunt, and Agnes Grey, nothing is more crucial to the development of Jane's character than the preservation of her right to speak. For voice is the trope par excellence of power in Jane Eyre. ${ }^{11}$

It is difficult in retrospect to grasp the radical departure represented by the first scene of the novel, as the orphan girl refuses the silent dependence that the governess novel established as necessity. As Ellen Moers says, "Before she gives Jane Eyre a name, or a class, or an age, Brontë makes her speaker both a person and a female in the quickest shorthand available to women writers: she has her say no." ${ }^{12}$ This refusal, which in contrast to similar rebellions in the governess novels has implicit narrative sanction, becomes translated in chapter 4 into the trope that will structure virtually every narrative turn: Jane's rejection of other people's representations of herself in favor of a "new way of talking" based on the authority of her own perceptions, feelings, and experience-that is, on an essentially Romantic authority. While the adult Mistriss Henley could question only in an ironic double voice her right to speak the truth against her husband, the child Jane can insist that she is "quite right" to speak ill of Mrs. Reed: "How dare you affirm that, Jane Eyre?" "How dare I, Mrs Reed? How dare I? Because it is the truth." Such "truth" telling gives Jane "the strangest sense of freedom, of triumph, I ever felt" (4.31). When telling her story to Miss Temple earns Jane public absolution from the accusations of Mr. Brocklehurst, the child has learned most of what she needs to know about voice: to refuse silence (and hence the values of the governess tale) as one refuses death: "I was no Helen Burns" (7.57).

Jane's struggle, then, is not to gain a voice but to sustain it in the face of increasingly seductive pressures to yield. Although she is submissive to Rochester in ways I find disturbing, she always bristles when

11. Several feminist critics have explored the importance of voice in Jane Eyre. See especially Janet H. Freeman, "Speech and Silence in Jane Eyre," SEL 24 (1984): 683-70o; and Rosemary Bodenheimer, "Jane Eyre in Search of Her Story," Papers on Language and Literature 16 (1980): 387-402.

12. Ellen Moers, Literary Women (New York: Doubleday, 1976), 24. 
he attempts to harness her voice or to disallow her point of view. She will not flatter him, will not be commanded to speak "for the mere sake of talking and showing off" (14.117), and when she refuses to become his mistress, it is the exercise of voice that licenses her as a "free human being with an independent will": "I have spoken my mind, and can go anywhere now" (23.223). Likewise, Jane is able to resist St. John Rivers's demands in a discourse in which, even though "he had not imagined that a woman would dare to speak so to a man," she herself "felt at home" (32.330), nor is she daunted when he tells her that "your words are such as ought not to be used: violent, unfeminine, and untrue" (35.363).

In order to have the authority to redefine both the "feminine" and the "true," Jane proceeds as if she must not only have $a$ voice but must have-and be-the voice. To achieve this hegemony, she must first of all vanquish the verbal authority of men, beginning with "Master Reed"- the master-reader?-whose rights Jane usurps when she throws his book at him. ${ }^{13}$ Mr. Brocklehurst, the clergyman who in a traditional governess tale would be a voice of truth, is entirely discredited. Rochester the "Master" tells outright lies about matters of which Jane has a crucial right to know. And holy as St. John Rivers may be, his coldness renders his voice mechanical, "his tongue a speaking instrument-nothing more." In refusing these male authorities, Jane Eyre severs the identification assumed in the governess novels between God's authority and man's. Jane's spiritual development is predicated on becoming her own religious authority, rejecting both Rochester's relativism and St. John's absolutes in order to fashion a morality and even a scripture of her own. ${ }^{14}$ Thus when Helen Burns tells her, for example, to "read the New Testament, and observe what Christ says, and ... make his word your rule," she flatly states that loving an enemy like John Reed is "impossible" (6.50), nor does the older narrator correct her as the narrator of the governess novel would be compelled to do. This moral self-centeredness is what allows Jane finally to leave first Rochester and then St. John despite each man's persuasive rhetoric; when she returns to Rochester, it is through neither God's power nor man's will: it was “ $m y$ time to assume ascendancy.

13. On reading in this novel see Mark M. Hennelly, Jr., "Jane Eyre's Reading Lesson," ELH $5^{1}$ (1984): 693-717; and Carla L. Peterson, The Determined Reader: Gender and Culture in the Novel from Napoleon to Victoria (New Brunswick, N.J.: Rutgers University Press, 1986), $82-131$.

14. For a fuller discussion of this point see Linda Peterson, Victorian Autobiography: The Tradition of Self-Interpretation (New Haven: Yale University Press, 1986), 132-35. 
$M y$ powers were in play and in force" (35.370). Given the audacity of this position, the curious last paragraph of Jane Eyre, with its emphasis on St. John Rivers and its concession to the voices of man and God, might be read as a reversion to the safe conventionality of the governess tale: "No fear of death will darken St. John's last hour: his mind will be unclouded; his heart will be undaunted, his hope will be sure, his faith steadfast. His own words are a pledge of this:-'My Master,' he says, 'has forewarned me. Daily He announces more distinctly,-_"Surely I come quickly!" and hourly I more eagerly respond,-_"Amen; even so, come, Lord Jesus!" , " (398). The dissonance of this bow to Christian rhetoric only underscores the degree to which Jane Eyre has been written against the authorities that license the governess tale. ${ }^{15}$ As character Jane has squelched every attempt to take over her story; as narrator she has been equally aggressive in suppressing points of view that differ from her own. For its historical moment, Jane's voice is an extraordinarily defiant fiction of authority. This is also, I think, why as both narrator and character Jane risks no humor, conscious ambiguity, or verbal play: her energies are necessarily bent upon keeping others-perhaps especially her "dear Reader"-from creating versions of her that might entrap her or threaten her representation of herself.

One cannot, of course, know the degree to which Charlotte Brontë was conscious of the unconventional narrative act that Jane Eyre constitutes, but this unconventionality might account for the narrator's self-conscious relationship with her narratee. One of the novel's oftremarked features is the frequency of its direct address: some thirty instances clustered toward the latter third of the narrative. I have already indicated that such consciousness also characterizes the governess novels but that contact in those novels takes the form of indirect acts of deference or defense; even Agnes Grey, which claims to be an intimate self-revelation, addresses the reader only in third-person forms. Nowhere in previous literature have I found a female personal voice so insistently, even compulsively, in contact with a public narratee in the manner of the "engaging" authorial narrators I described in Chapter 5 .

Some critics have noticed-or deplored-the seemingly gratuitous

15. The ending is also, as Gayatri Chakravorty Spivak argues and as my discussion below will reinforce, a re-turn toward imperialist evangelism as the pre-text for this text. See "Three Women's Texts and a Critique of Imperialism," in "Race," Writing, and Difference, ed. Henry Louis Gates, Jr. (Chicago: University of Chicago Press, 1986), 267-68. 
nature of these addresses. Sylvère Monod finds them defensive and intrusive; Karl Kroeber notes they are rarely "required by the immediate situation," and thus seem arbitrary like the comments of Eliot's narrators in Clerical Life and Adam Bede ${ }^{16}$ This "arbitrariness" suggests that the desire to evoke the reader is motivated less by the daring nature of the story than by the daring nature of its voice, or rather by the narrator's wish to be accepted despite her unconventional assertiveness. Just as the novel's suppression of retrospectivity re-creates the immediacy of epistolary fiction, I believe the name "Reader" functions as a substitute for the epistolary proper name, recapturing in a public fiction the intimacy of epistolarity in a way much more immediate than Agnes Grey's effort to capture the intimacy of the diary. The fact that "Reader" is always named in the singulara distinct contrast to the "engaging" practices of Stowe and Eliot, who construct various narratees of both sexes-reinforces the use of the public narratee as confidant in evocations that resemble acts of epistolary address: "True, reader, and I knew and felt this ... "(Chap. 9); "I have told you, reader, that I had learnt to love Mr Rochester" (Chap. 18); "Gentle reader, may you never feel what I then felt!" (Chap. 27); "Reader, it was on a Monday night..." (Chap. 37). The search for contact implied in these addresses certainly corresponds to the behavior of Jane as character, for voice is to her as much the trope of intimacy as of power. Jane "could never rest in communication with strong, discreet and refined minds, whether male or female, till I had passed the outworks of conventional reserve, and crossed the threshold of confidence, and won a place by their heart's very hearthstone" (32.330). It is of course through voice-the mysterious voice Jane hears from "somewhere" that cries "Jane! Jane! Jane!" (35.369) —that she is called back to Rochester, and marital happiness is the pleasure of talking "all day long" (38.397). The goal for Jane as both narrator and character is to achieve this intimacy without trading voice for love.

A kind of public epistolarity becomes the narrative sign, then, of Jane's quest for such a blend of intimacy and autonomy. Who can blame her (to paraphrase Jane) if, abandoned by family and publicly shamed, Jane might anxiously seek the approval of a larger audience? At Lowood, when Jane is af raid that "everybody" will think her a liar,

16. Sylvère Monod, "Charlotte Brontë and the Thirty 'Readers' of Jane Eyre," in Jane Eyre (New York: Norton, 1971), 496-507; and Karl Kroeber, Style in Fictional Structure (Princeton: Princeton University Press, 1971), 46. 
Helen Burns answers whimsically, "Everybody, Jane? Why, there are only eighty people who have heard you called so, and the world contains hundreds of millions" (8). Jane can address these "hundreds of millions" by writing her story as a kind of public letter to the world. It is no accident, I think, that in this same chapter she tells us she has been learning to conjugate the French verb être, or that, as Mark Hennelly observes, Jane's initials, which identify her paintings and which remain unaltered even when she takes on a pseudonym at Marsh End, spell the French $j e .{ }^{17}$ For Jane, the orphan-woman asserting personal identity against the powers of silencing, to tell is to exist. And although the novel ends in marriage, so that at the time of writing Jane Eyre is in fact Jane Rochester, the narrator never yields her "J-E," her proper name, and her autobiography appropriately remains Jane Eyre. One could argue that this retention of her name, along with Jane's "Reader, I married him" (38.395), in contrast to Juliette Catesby's passive "they married me" and Ossery's appropriative "there is no more Juliette Catesby," takes control of the conventional marriage plot so that, as Rachel Brownstein says, her marriage "defiantly affirms not the heroine's transformation but her remaining herself." ${ }^{18}$ In this respect Jane Eyre also rewrites the tradition in which marriage effects the heroine's silence, though the fact that the story ceases with marriage perpetuates what I suggested in Chapter 8 (and will suggest again below) to be a continuing problem in the history of female voice.

Because its singular and insistent voice does not falter before a public audience, Jane Eyre dramatically widens the space for female personal voice in fiction: it extends to privileged-class women the fiction of individual authority that Romanticism had consolidated for privileged-class men. If "books continue each other," 19 Jane Eyre surely helped to foster the tradition of the Bildungsroman that burgeons after 1847 . It is conventional in literary criticism to assume a one-way influence of men's work upon women's; I suspect that the influence of Jane Eyre upon fictional autobiography by men has not been told, and that the similarities Carla Peterson has noted between Jane Eyre and David Copperfield may be more than shared signs of the literary times. ${ }^{20}$

17. Hennelly, “Jane Eyre's Reading Lesson," 703.

18. Rachel Brownstein, Becoming a Heroine (New York: Viking, 1982 ), 156.

19. Woolf, A Room of One's Own, 84 .

20. Carla L. Peterson, The Determined Reader: Gender and Culture in the Novel from Napoleon to Victoria (New Brunswick, N.J.: Rutgers University Press, 1 986), 84-85. See also F. R. Leavis and Q. D. Leavis, Dickens the Novelist (London: Chatto and Windus, 1970), 108-10. 
Ellen Moers suggests as much when she notes that the first three chapters of Jane Eyre, "including the crisis of pre-pubic sexuality that is their climax, is the female equivalent to chapters 2,3 , and 4 in David Copperfield, the classic Victorian dramatization of the Oedipal crisis in a boy's life, which Dickens wrote after he read Jane Eyre." Moers also reminds us how daring Jane's voice is when she notes that David would never use the "hostile negatives" that Jane spits at John Reed. ${ }^{21}$

If the influence of Jane Eyre on male novelists remains unacknowledged, women writers from Elizabeth Barrett Browning and Harriet Martineau to Doris Lessing and Adrienne Rich have named the novel as a primary authorizing source. Even Virginia Woolf, in the guise of criticizing Brontë in A Room of One's Own, uses Jane's outspoken voice when she cites at length the "who shall blame me?" passage that she is ostensibly condemning for "sex-consciousness." 22 Jane Eyre seems to have been the acknowledged starting point for a tradition of fictional autobiography by women in a way that, as Elaine Showalter says, was "felt to have been revolutionary." ${ }^{23}$ One early successor, perhaps the first female autobiography in American fiction and written by a proclaimed admirer of the Brontës, is Elizabeth Stoddard's The Morgesons (1862), which (using the first name of another Jane's sister) creates in Cassandra Morgeson a strong-willed figure whose fictional story begins like Jane's when she is ten and avidly reading ("unprofitable stories" rather than religious tracts), and ends like Jane's with an epilogue announcing her marriage and describing her happiness. In later decades other women in Europe, the United States, and the British Commonwealth constituted outspoken narrators who claim and defend forms of independence more radical than Jane's, of ten eschewing marriage for sexual freedom and professional life: Miles Franklin's My Brilliant Career (1901), Mary Hunter Austin's A Woman of Genius (1912), Colette's La Vagabonde (1911).

Still, "the difficulty of saying 'I'" in public voice is by no means ended with Jane Eyre. Brontë herself, perhaps responding, as Nina Auerbach suggests, to her own overconsolidation of subjectivity in Jane Eyre, creates in Villette a far more elusive and complex narrator

21. Moers, Literary Women, 24.

22. Woolf, A Room of One's Own, 71-73.

23. Elaine Showalter, A Literature of Their Own: British Women Novelists from Brontë to Lessing (Princeton: Princeton University Press, 1977), 122. 
who withholds her story as compulsively as Jane tells hers. ${ }^{24}$ Jane Eyre's (and for that matter Villette's) fidelity to marital teleology may only have reinforced the conventions that, I argue, restrain personal voice for married women, for the ambiguous voice of the censored woman continues most visibly in fictions that represent their narrators as wives or fiancées. In both Dinah Craik's A Life for a Life (1859) and Charlotte Perkins Gilman's The Yellow Wallpaper (1892), for example, the narrators speak a complex language of indirection even though their writing is ostensibly directed only to the "dead paper" of a diary. And until the 197 os personal voice has remained unquestionably a practice chosen less frequently by women than by men. For Marguerite Yourcenar, writing in the 1920 , for example, the representation of female voice was simply unthinkable: "Another thing virtually impossible, to take a feminine character as a central figure, to make Plotina, for example, rather than Hadrian, the axis of my narrative. Women's lives are much too limited, or else too secret. If a woman does recount her own life she is promptly reproached for being no longer truly feminine. It is already hard enough to give some element of truth to the utterances of a man." ${ }^{25}$ This may be why Proust's A la recherche du temps perdu is a personal narrative while Dorothy Richardson's Pilgrimage is not-a difference of major significance, I argue, insofar as the "I"-protagonist can represent the act of narration as well as the narrated event. There is clearly some relationship between political progress and personal voice: when Sylvia Plath's The Bell Jar appeared in 1963 , it ruptured an American literary scene shaped by the conservative gender ideology of the 1950 os and dominated by the male narrators of J. D. Salinger, Norman Mailer, and Philip Roth, while the feminist movement of the early 1970 soon produced female autobiographical fictions like Rita Mae Brown's lesbian picaresque $R u$ byfruit Jungle and Erica Jong's heterosexual adventure Fear of Flying (both 1973). Yet even in the 1970s, Mary Gordon admits to writing the first draft of Final Payments (1978) "in the third person" because "I wanted to sound serious. I didn't want to be embarrassing." 6

24. Nina Auerbach, "Victorian Players and Sages," paper delivered at Georgetown University Literary Criticism Conference, June 1988.

25. Marguerite Yourcenar, "Reflections on the Composition of Memoirs of Hadrian," in Memoirs of Hadrian and Reflections on the Composition of Memoirs of Hadrian, trans. Grace Frick (New York: Farrar, Straus, and Giroux, 1963), 327-28.

26. Mary Gordon, "The Parable of the Cave or: In Praise of Watercolors," in The Writer on Her Work, ed. Janet Sternburg (New York: Norton, 1980), 30. 
By the mid-1980s, however, public female personal voice in fiction had become for white Western women as conventional as private female voice was two hundred years ago. ${ }^{27}$ One sign of this conventionality also repeats eighteenth-century literary history: today men are once again writing fiction in the female voice. Such novels, which include (to name a random few) Wright Morris's Plains Song (1980), Reynolds Price's Kate Vaiden (1986), J. M. Coetzee's Foe (1986), Richard Babcock's Martha Calhoun (1987), Michael Dorris's A Yellow Raft in Blue Water (1987), John Updike's S. (1988), and Allan Gurganus's Oldest Living Confederate Widow Tells All (1989), offer perhaps as varied a spectrum of representations of female voice as did men's fictions two hundred years earlier: primarily sympathetic, sometimes feminist, occasionally misogynist. Like the eighteenth-century parallel, this resurgence in men's writings suggests to me both a new empathy and an old opportunity to recuperate female authority.

If Jane Eyre helped to inaugurate the tradition that has led to this new resurgence of female voice, however, Brontë's novel and the tradition it launched have also created a dangerous legacy signified by the gaps in my own examples-a legacy I suspect is a logical rather than accidental result of the terms of Jane Eyre's authority. I have already stated that Jane the character must silence all voices; I want to argue now that Jane's authority is also predicated upon the novel's production-precisely in order to dehumanize and disempower itof a voice far bolder and more singular than hers: the voice of the Creole woman Bertha Mason Rochester. Brontë's use of a Caribbean woman as Jane's "mad" and silenced double is of course the very sign of the subjugation that Victorian Empire demands. ${ }^{28}$ Jane Eyre's project to construct the outspoken and insubordinate Jane as legitimately feminine succeeds by denying Bertha's femininity: she is large and "virile," "athletic" and "corpulent" (25.250), her face is "discoloured"-not white?-and "savage," (25.249); she has a "pigmy intel-

27. William H. Gass claimed in 1987 that of 195 recent novels he had examined, "eightyone were in the first person"; he (unhappily) proclaimed the three most visible trends in fiction to be "an increase in women, first persons and present tenses" in numbers that go "through the roof." In "A Failing Grade for the Present Tense," New York Times Book Review (11 October 1987), 32.

28. This recognition is, of course, what impelled Jean Rhys to give Bertha a narrative voice and a West Indian name in Wide Sargasso Sea (1966). The best-known critical reading of the relationship between Jane and Bertha reproduces the text's own relations of power by making Bertha Jane's mirror. See Sandra Gilbert and Susan Gubar, The Madwoman in The Attic (New Haven: Yale University Press, 1979), 336-71. 
lect," is but a "demon," a "harlot," a "thing" (27.271). Here blatantly dramatized is the "splitting of the female image" for purposes of domination," ${ }^{29}$ in which the black woman is first exoticized and then bestialized into a "masculinized, domineering, amazonic creature" of "animalistic, subhuman strength" who gives the white "lady" her identity. ${ }^{30}$ In a fictional world whose pervasive imperialism is also reflected in the missionary activities of St. John Rivers, and whose Anglocentrism discredits even the "foreign" European women with whom Rochester associates, the most foreign woman of all must be "killed off," as Gayatri Spivak says, so that "Jane Eyre can become the feminist individualist heroine of British fiction." 31

While this novel clearly reveals imperialism to be the unacknowledged foundation for its narrator's hegemonic authority, what is especially significant for the purposes of my discussion is the representation of Bertha as a woman with a voice gone wrong. None of Bertha's qualities receives more attention than her voice: the "mirthless" laugh (11.93), as "tragic" and "preternatural a laugh as any I ever heard" (1 11.94$)$, which gives Jane the first clues to Bertha's existence; "her eccentric murmurs; stranger than her laugh," the "oral oddities" and frightening "sounds" for which Jane cannot "account" (12.96), the doglike snarls, "savage, sharp, [and] shrilly," that "ran from end to end of Thornfield Hall" (2.181). As Jane's voice signifies her fitness for Rochester, Bertha's crystallizes her failures as wife: conversation with her is impossible "because whatever topic I started immediately received from her a turn at once coarse and trite, perverse and imbecile"; servants refused to live with "the continued outbreaks of her violent and unreasonable temper" (27.269); "no professed harlot ever had a fouler vocabulary than she" (27.271); and it is her "yells" that finally lead Rochester to leave the "hell" of the Indies for England's "whispering" wind (27.271).

But what is Bertha's voice if not the voice of the woman who refuses entirely both "women's language" and woman's place-in-

29. Adrienne Rich, "Disloyal to Civilization: Feminism, Racism, Gynephobia" (1978), in On Lies, Secrets, and Silence, 291. Rich, too, slides past the question of race when writing in 1973 about Bertha as Jane's double. See "Jane Eyre: The Temptations of a Motherless Woman," in Lies, Secrets, and Silence, 98-100.

3o. Bell Hooks, Ain't I a Woman? Black Women and Feminism (Boston: South End Press, $1981), 81-82$.

31. Spivak, "Three Women's Texts and a Critique of Imperialism," $26_{5}$. 
deed, the entire symbolic order-the voice (of the semiotic chora?) against which Jane's verbal audacity gets contained and normalized? ? $^{32}$ The fact that Jane is not a "blonde, blue-eyed doll" but is herself dark and as a child was "savage" suggests that she is already dangerously like Bertha; that Jane is not the submissive traditional governess suggests that her voice must be shown to have limits of its own. Bertha's uncontrollable voice, which insists on being heard even when her body is shackled, is the frame that makes safe Jane's outspokenness and reveals it as ultimately unthreatening to the social order: precisely because Jane's voice must vanquish the voices of men, it must also be distinguished from the violent, angry mockery of the woman whom white patriarchy cannot restrain, the dark woman brought in chains to foreign shores. Thus just as Romantic narrative constructed authority as essentially masculine, so Jane Eyre legitimates female authority as essentially white. Indeed, authoritative voice in Jane Eyre is even more parochial, for it belongs finally only to white educated Christian Englishwomen of the middle class; Mrs. Fairfax, the housekeeper, has "no notion of sketching a character, or observing and describing salient points" (11.92), the housemaid Sophie is "not of a descriptive or narrative turn" (12.96), and the wealthy Blanche Ingram "was not original; she used to repeat sounding phrases from books" (18.163).

In this light, Jane's extraordinary narrative authority becomes insidious. At Lowood, Jane must learn to temper her voice for reasons of strategy; under Helen's advice she is able to "arrange" her story "coherently," so that "thus restrained and simplified," it "sounded more credible" (8.62). If Jane Eyre repeats for a more public audience precisely this gesture, then the text has revealed in spite of itself the concealed incompleteness that its own singular authority demands. If the powerful voice achieved by Jane Eyre helped to foster a tradition of outspoken white female narrators in novels since the mid-nineteenth century, the very hegemony of that tradition, brought into being by the dramatized silencing of Bertha Mason, must also have helped to foreclose narrative possibilities for women novelists of color writing in the West. I make this claim as more than hypothesis, for the evidence at least of the AfricanAmerican women's writings discussed in the next chapter over-

32. Such a notion is supported by Gilbert and Gubar's observation that Bertha's entrances in the text are typically "associated with an experience (or repression) of anger on Jane's part." In The Madwoman in the Attic, 360. 
whelmingly supports just this racial split in women's narrative possibilities. If Jane's voice can be empowered only through the silencing of other women's voices, then Jane Eyre unwittingly exposes the dangers of its own authority and makes clear that the difference of gender is not difference enough. 